\title{
The Policy Orientation of the European Left Wing in the Context of Refugee Crisis
}

\author{
Chen Mingzhu \\ Department of Political Science Shandong Academy Governance, Jinan 250014 China
}

Keywords: Refugee crisis; European left-wing political parties; Joint; Policy

\begin{abstract}
Since the beginning of 2014, the persistent refugee crisis has brought great impact on the traditional economic and political order in Europe. As an important force in European politics, the left Wing parties in Europe are expected to ease the conflict by supporting the refugees, exposing the nature of the crisis, and highlighting the joint action. But in the long run, if the European left-wing parties want to achieve their goals of the resolution of the crisis, they must be on the basis of re-examine the judgments of the European public opinion, to revise many European foreign policy, to promote building effective integration of Christian and Muslim culture policy platform between internal multinational, mufti-parties and inner-party, all that can help them to solve the current crisis in Europe and avoid the "splitting" of Europe.
\end{abstract}

\section{Introduction}

The rise and fall of European left-wing parties are closely related to the economic and political changes in Europe. Before the collapse of the Soviet Union to the European refugee crisis, the European left-wing hoping to occupy a space on European political platform, but the changes of situation always let it backfired, and put them present "power ups and downs" in the alternation of the situation. The only thing that can not be denied is that, in the birthplace of the socialist ideological trend, the European left-wing parties will be active when they are in a dilemma. In a period of time, regional conflicts and local wars in West Asia and North Africa produced a large number of cross-border refugees arrived in Europe, the attitude towards refugees of European Society , European government's "accusing each other" on refugee policy, the melancholy reality -- public discontent, multiple terrorist attacks, Europe extreme right-wing parties rise of the situation, all that have to let us think of a question: Under the double dilemma of refugee crisis, financial crisis, What the European left-wing parties' new policy trends should be within slow recovery Europe?

\section{The challenge of the European left-wing party: the refugee crisis and the logic of the construction of European traditional order}

It can be recognized that the refugee crisis in European countries especially in traditional European countries like UK, France, German have more disadvantages impact than benefit, after the financial crisis has not yet completely eased, the European traditional order is facing the challenge of reconstruction again. For the left wing parties in Europe, the background of the policy choice becomes more complicated.

Firstly, the worse economy. The admission of millions of refugees is a burden to Europe which has not yet recovered from the debt crisis. For example, the main refugees "entrance gate" countries --Italy, Spain, Greece, are the more serious debt crisis hit countries, their financial problems under the circumstances are gloomy, they have no confidence completely digested an large increasing number of refugees ,the "best" choice is let refugees "via to the North". Even in Germany, where the economy is better is also the burden of German economic development to take into account the expenditure of the resettlement of refugees. As for the "cradle to grave" welfare policy to become refugees "yearning" Nordic countries are also in the tightening of refugee policy due to the pressure of welfare and medical system. Sweden, once the most friendly countries to refugees, has 
announced a change in its original liberal refugee policy and increased its presence on the eastern border. It is true that the younger age structure of refugees can help to ease the crisis in Europe's growing population aging crisis, while addressing the issue of refugee education may also promote the full employment of the European education system. But, overall, the refugee crisis will drag the economy's recovery is a fact. After the EU enlargement, there is exacerbated imbalance of economic development between EU countries. Now the European strong humanism can not all inclusive economic downturn brought by the mess, the contradiction between moral and practical ability to rescue is prominent. Therefore, in the short term, the refugee crisis is more harmful to the European economy.

Second, "tearing" and stale politics. In twenty-first Century, the EU as a diversified community is an important force in the world's pattern, but the refugee crisis enlarge differences between EU countries, the economic imbalance provoked an rising "anti European" and "Eurosceptics" doctrine in the European Union, the possibility of tearing is unprecedented obvious. For example, the refugee attack the EU common boundary of expanding, in addition to the boundary country abandoned the "Dublin Convention", refugee quota scheme at the European level has been unable to form a unified opinion. There is also country accrual like United Kingdom, rare sight of the interests make it referendum to achieve the removal of Europe. It can be said that the governance mechanism and EU members solidarity and consensus are by the severe challenges hitherto unknown of the refugee crisis, Europe's "humanitarian" collapse in mutually making excuses. Secondly, in view of the arrival of refugees, rising non-traditional security issues and terrorist activities in European countries appear the deterioration of social order in EU countries, citizens' view of refugees is changing, the arrival of refugees boycott emotions as one falls another rises. After the Second World War, the European countries in the reflection of German Nazi racism keep a lookout of political extremism, such as Racism, Nazism, Xenophobia.But the frequent events resulting in the above political extremist ideology arise, the most famous is the German Pegida Movement. Extreme Right-wing parties of Anti immigrant and opposition to European integration of the Suspected Europe parties make the European extreme right-wing force on the possibility of increasing, the recent election trend of several big European countries also reflects that fact. Therefore, the cohesion which has not yet stable of EU expansion is weakening in the refugee crisis, unpredictable political trends emerge within EU countries.

Third, Cultural fault lines difficult to bridge. Samuel Huntington describes the differences of world culture in The Cultural Conflict and The Reconstruction of World Order. At present, with the continuous influx of a large number of refugees in Europe, Muslim religious cultural values and the European mainstream values conflict caused by differences in number, the fundamentalist Islam extreme autocracy which advocating violence, terror makes the Europeans whose idea of freedom, equality, fraternity feel difficult to accept. As a result, the Muslim ethnic group has become the most difficult foreign immigrants in the European countries, and the social integration of the Muslim population has a sharp trend. In addition, from the cultural differences between Western Europe and Eastern Europe ,"Visegrad" Group adhere to their own traditional cultural nationalism, highlighting its own Christian traditions, maintains a" Christian Europe ", rejection of European multiculturalism. Therefore, compared to Western Europe, Eastern European countries' attitude towards refugees are more indifference. And, though as young group of refugees in host countries can obtain good language, vocational education engaged in the work which can alleviate the labor shortage of European countries' aging problem. But for now, Europe generally higher labor skills requirements, and the complicated labor rules and regulations is more likely to be filter refugees, even become purified population distribution law in the workplace. For example, In 2015, the Swedish accept of more than 160000 refugees, fewer than 500 people found work. So, in the future refugees who has been or will soon settled in Europe if not effectively realize social integration, non-traditional security threats will increase in the European countries. Europe will become the most intense blend collision area of the cultural fault line.In a word, Cultural social problem brought by European refugees is deeper than the influence of the economic problems.

Taken together, although it is difficult to give a last word of development direction of Europe 
which under the extrusion of double crisis, but as you can see, the refugee crisis brings European division and conflict under the superposition of multiple factors. Traditional relatively strong relationship between members of the European Union has shifted from the unity cooperation to mutual distrust, Europe also needs to maintain the policy to normalize relations with the Middle East and north Africa countries. And the power of the traditional European political parties also in reverse, many marginalized party bumps. Although the European left-wing political parties did not grasp the the opportunity of turn Europe "Left" after financial crisis. Now standing in the transfer from "Centre-right" to"Far-right", the policy orientation of left-wing parties in Europe should be striking and useful.

\section{The policy choice of the main European left-wing political parties in the context of refugee crisis}

In general, according to the position of political parties in the political map of the parties, the European left-wing political parties, including the traditional left wing political party (moderate left), radical left wing and extreme left party. For the current refugee crisis, both the ruling left-wing parties or opposition left-wing parties choose their orientation reflects the reality of the European policy of electoral politics under the helpless.

\subsection{Traditional left-wing parties' choice in dilemma}

Before the refugee crisis broke out, in order to cater to the needs of the European reality electoral politics, the traditional left-wing parties used to shape himself as "a national party", but the proposed policy itself is fragmented, and even tinkering with the party policy of new liberalism, leading to its easy to lose its traditional support for its firm supporter, make it appeared in the election dilemma situation. When refugee crisis comes, traditional left-wing parties facing the reality of political influence weakened, also can't promote their traditional values and shout enhance the level of refugee welfare by cutting public spending, so its control and redistribution of refugee crisis policy as a whole is shown slightly awkward. For Britain, the Left argues that emphasizes the social cost of immigrants and ignore immigrants' contribution to social wealth and cultural diversity is not fair, on the background of eurosceptic caused by the refugees' coming of UK, the opposition Labor Party boycott Britain from the European Union and called on to help the refugees in the Middle East, at the same time support humanitarian aid for refugees. In France of the ruling social Democrats, on the other hand, influenced by the French's economy situation, right deviation, limited reception ability of refugees and the refugees application cycle is longer than the other countries, the ruling social Democrats attitude towards refugees is "render humanitarian tradition, but the lack of substantive action". In 2015, for example, French prime minister Valls said that the under the policy framework of refugees of EU, France can accept 30000 refugees, but no more than this number. In Germany, after Martin Schulz became a social democratic party leader, Schultz said on many occasions to support Merkel's administration of refugees, humanitarian aid, and also he said that if the refugees violate the law should be punished by the law, he also called for efforts to eliminate the root causes of the refugees chose to leave the hometown in Africa and the Middle East. Austria's attitude towards refugee is changeable, before Iman's resignation, the ruling Social Democratic Party put forward in the further tightening of refugee policies and propose an orderly and humane way to solve the refugee crisis. In general, the traditional European left-wing party as a political force of European ruling force, they generally support to humanitarian assistance to refugees, but due to different level of political and economic development of all countries , their acceptance attitude of the refugee also differently.

\subsection{The constructive criticism of radical leftist party}

After the financial crisis in Europe, the European mainstream right-wing parties and Traditional Left-wing Social Democrats generally weak response to the economic crisis of the state, some anti austerity policies of the radical left especially cater to the common needs of the public, so the later show dazzling election results. After the radical left absorbed some of the ideas of the new social 
movement in Europe, it was more inclined to build a democratic, welfare, ecological, feminist, and peaceful Europe. Therefore, after the refugee crisis, although most of the radical left-wing parties in Europe are in the position of the opposition party or coalition, they have expounded their own crisis proposition. Some of the country's Communist Party standing in the ideological point of view that the refugee crisis is reflected the crisis of the capitalist system, is the embodiment of Western imperialist intervention policy and the system of exploitation and oppression brought poverty, class antagonism, so the crisis reflects the greed of capitalism. In view of this, the radical left called on the people of all countries to unite with the goal of fighting against imperialism, and put forward the policy of returning refugees to their homes. For example, from the point of view of eliminating the root causes of the crisis, the Irish Communist Party advocated that the end of the United States, NATO military intervention in the Middle East is the fundamental solution to the crisis. To some extent, some radical left-wing parties have proposed that humanitarian assistance should be given to refugees. The French Communist Party emphasis the need to abide the Geneva agreement and set up a refugee reception center which according to the provisions of the United Nations refugee agency, also with the creation of social health care, education and other channels to protect the rights of refugees. At the same time The French Communist Party also advocated to abolish the "oppression" mechanism like the Schengen and Dublin agreement in the framework of the United Nations, the revised European and French refugee immigration policy to reject the indifference of injustice to the refugees. In addition, from the implementation of "workers of the world unite" point of view, the radical left-wing parties consider that make use of international assistance in the stable output of refugees. For example, the Communist Party of Greece is considered to strengthen the cooperation between proletariat in various countries, emphasizing the Communist Party and the interests of workers for the PKK to strengthen coordination between different regions, getting rid of the system root of the crisis. Overall, due to the European Union Party established rules in various countries and the radical left parties are basically no restrictions governing, although some of the radical left can propose refugee welfare policies but can't present a system and full support solution by the whole European countries to the problem.

\subsection{Finally, the idea of the extreme left}

The extreme left-wing's influence on European electoral politics is very limited, at the same time the extreme left advocate the realization of communism by non parliamentary and revolutionary means, so as the persistent presence of organizations in European politics, its policy orientation is to comment on the ruling party's refugee policy with protests. For example, the "We Can" Party of Spain rise after the financial crisis advocating assistance to refugees, and criticize the prime minister Rajoy signing the refugee repatriation protocol with Turkey.

To sum up, under the background of relatively mature democracies and relatively prosperous market economy in Europe, the traditional goal of the left party is to improve the living conditions of the people of different classes in the framework of development. So, in any case, as a principle of distribution, the left wing of Europe is basically in favor of social citizenship and does not exclude the acceptance of refugees of any race. On the basis of such a consensus, the European left-wing parties stand on the position of refugees to welcome refugees. But Looking at the action of most of the left-wing parties in Europe : Firstly, subject to the limitation of the ruling position, their policy can only support the refugees by slogan, but not put into practice, when sharing refugee quotas threaten the core value of left-wing party's identity, left-wing political parties, especially the ruling left-wing parties are likely to show "Noninterference" feature; Secondly, although European left-wing parties understand that the united way is the best way to solve the refugee crisis, but the different attitudes of EU and European integration leads the left-wing parties in Europe except certain consensus in opposition to neoliberal, welfare cuts and the rights of workers policies. Besides, the left party is more shouting slogans but joint no condensation point of consensus. From the current point of view, the left-wing parties in Europe policy facing many realistic dilemma after the financial crisis, the unbalanced development status of the left is not eliminated, although the left policy orientation is to establish an effective mechanism to reconstruct the situation of peaceful, 
harmony and balance of Europe , but like the fact of the First World War that European countries in the background of the pacifist socialist party only to "support the war" , the refugee crisis can also lead to the second international division, if the refugee crisis in the national political level of the EU can not reach consensus, then the European socialist in their field can only be "forced" to support their own countries. the EU is torn again, the possibility of the European Left Wing socialist divergence is also great.

\section{The Future Policy Orientation of The European left-wing Parties}

Compared with the right-wing parties, the goal of the European Left Party is to be able to occupy a place in the country's political system - in power or have the right to speak. But the decisive factor of the European vote politics is the vote and friends, that is, the political trend of Europe is associated with the people's psychology, political events and many other factors. Therefore, the socialist left party in the crisis at the moment need to judge the current constraints of their own and Europe, and carefully to make appropriate policy choices.

Generally speaking, the left-wing parties policy orientation in Europe's refugee should not succumb to the short term, but should be focus on the long term, because if they can not correctly grasp of public opinion, their overall development trend may not only lose a opportunity or not be able to turn the right deviation neutralizing, which be on the cards led to left-wing more marginalization. To sum up, in the present Europe, the effective refugee management policy which is easy to get the votes needs to have the following characteristics: 1 . Demands easing the international relations. War is the birth of refugees, also it is the factor European people general resistance, so the left-wing parties in Europe needs to relocate European countries on relationship between Europe and America ,also they have to prudently consider the harm of American's hegemony and New interventionism brought to Europe, at the same time take account of refugees countermeasures with West Asian and North African countries including Turkey's. In fact, all of the European left-wing parties are clear that the future destiny of Europe, has become increasingly unable to separate from the world, but it can not be tied to the "West" wheel.2, the acceptance of the left-wing party policy by public. After 1990s, the European Left Social Democratic Party to election as the center "strategy of intermediate strategy, now, this transformation is to cater to the new middle class, but ignored the traditional left support of the working class, and compromise to new liberalism, not reconcile this contradiction. Now the European common trouble is not refugees but terrorism, and the arrival of refugees is more basic public rights occupy lower citizens, thus more

likely to impact the attitude of the original supporters of left-wing parties. So, after the left-wing parties in Europe should be a long-term perspective to magnify the benefits of Europeanization to European refugees.

\section{Acknowledgement}

This research is based on the project results of Innovative engineering project of Shandong Academy Governance in 2017: “The Policy Orientation of the European Left Wing in the Context of Refugee Crisis” (No.2017KY029).

\section{References}

[1] Junjie Zhao(2016).Special report on refugee crisis in Europe. Beijing: China Social Sciences Press.

[2] Dewen Tian (2017). The refugee crisis is still in progress, and European conflicts are intensifying. People's Forum,18,33-35.

[3] Patrick Kingsley (2017). My unfailing sufferings: a complete record of the refugee crisis in Europe. Beijing: CITIC Publishing House.

[4] Quancheng Song (2017). New Characteristics and Causes of the European Refugee Crisis in 
2016: Empirical Study Based on the Data of the European Statistical Office and the German Federal Bureau of Immigration and Refugees in 2015-2016.German Research,32(03):40-53+134.

[5] Office of the United Nations High Commissioner for Refugees (2017). Convention and Protocol relating to the Status of Refugees. http://www.unhcr.org/protect/PROTECTION/3b66c2aa10.

[6] Chunrong Zheng, Xiaoshan Ni (2016). The Challenge and Response of German Refugee Integration in the Context of Refugee Crisis. Foreign Social Sciences, 6,75-83. 